\title{
Foraging Behavior of Alberes Cattle in a Mediterranean Forest Ecosystem
}

\author{
Jordi Bartolomé, Josefina Plaixats, ${ }_{1}^{1}$ Jesús Piedrafita, ${ }^{2}$ Marta Fina, ${ }^{3}$ Eduard Adrobau, ${ }^{4}$ Aida Aixàs, ${ }^{4}$ \\ Marina Bonet, ${ }^{4}$ Jordi Grau, ${ }^{4}$ and Lluis Polo ${ }^{5}$
}

Authors are ${ }^{1}$ Professors, ${ }^{2}$ Full Professor, and ${ }^{3}$ PhD Student, Ruminants Research Group, Animal Science and Food Department, Autonomous University of Barcelona, 08193 Bellaterra, Barcelona, Spain; and ${ }^{4}$ PhD Students and ${ }^{5}$ Professor, Environmental Science Department, University of Girona, 17071 Girona, Spain.

\begin{abstract}
The dietary composition of the semiferal cattle population in the Alberes Natural Park in northeastern Spain was determined four times per year, from June 2002 to February 2004, by microhistological analysis of a total of 120 fecal samples. Woody species, mainly the Quercus and Erica genera, formed the bulk of the diet, reaching $89 \%$ of it in winter. However, in spring and summer, the proportion of woody and herbaceous species varied between samples, depending on the habitat where they were collected. The forest samples contained $67 \%$ woody species in summer, whereas grassland samples only contained $44 \%$. The results showed that the Alberes cattle population grazed actively in Mediterranean forests and consumed a high proportion of the most combustible species, such as the Erica genus (39\% of the epidermal fragments in winter samples). Even when grassland habitat was utilized, in spring and summer, one-third of the diet was from woody species. Some bovines, such as the Alberes cattle breed, can therefore survive year-round in a forest habitat with little forage supplementation, and the consumption of a predominantly woody diet would be expected to reduce forest fire hazards.
\end{abstract}

\section{Resumen}

En este trabajo se determinó la composición anual de la dieta de una población semi-salvaje que habita el Parque Natural de la Albera (Paratge Natural d'Interès Nacional de l'Albera) en el NE de España. El estudio se llevó a cabo desde Junio de 2002 hasta Junio de 2004, a partir del análisis del contenido de 120 muestras fecales. Las especies leñosas, principalmente de los géneros Quercus y Erica constituyeron la mayor parte de la dieta, alcanzando el $89 \%$ de la misma en invierno. Sin embargo, en primavera y verano la proporción de especies leñosas y herbáceas fue diferente según el hábitat donde se recogieron las muestras. Las muestras recogidas en los bosques tuvieron el $67 \%$ de especies leñosas en verano mientras que las recogidas en los pastizales solamente un $44 \%$. Los resultados muestran que la población de ganado Alberes pastorea activamente en los bosques Mediterráneos y consume altas proporciones (39\% de los fragmentos epidérmicos en las muestras de invierno) del género Erica, cuyas especies son altamente combustibles. Se concluye que algunos bovinos, como la raza Alberes, pueden sobrevivir a lo largo del año en ambientes forestales, con escasa suplementación de alimento y que además el hecho de mantener una dieta predominantemente leñosa podría contribuir a reducir el riesgo de incendio forestal.

Key Words: diet selection, fire hazard, habitat selection, microhistological analysis, Quercus, woodland

\section{INTRODUCTION}

The Alberes is an indigenous Spanish bovine breed, the characteristics of which have been described by several authors (Mascort Mariani 1957; Casellas et al. 2004; Fina et al. 2008). It is a small-framed animal, with males weighing $350 \mathrm{~kg}$ and females $275 \mathrm{~kg}$, and has a straight cranial profile and short horns. Animals of this breed live in a semiferal state in the Alberes Natural Park in the Eastern Pyrenees. Alberes animals have traditionally been assumed to show a preference for forest feeding and high rusticity (Budó 2000). These characteristics could be an opportunity to learn more about the broader benefits of managing woodlands with livestock. Benefits of biodiversity, for instance, can be achieved by reducing the

This research was funded by the Departament d'Agricultura, Ramaderia i Pesca (Generalitat de Catalunya) and the FEDER-Intereg IIIA project "L'Albera: memoria i terra."

Correspondence: Jordi Bartolomé Filella, Ruminants Research Group, Animal Science and Food Department, Autonomous University of Barcelona, 08193 Bellaterra, Barcelona, Spain. Email: jordi.bartolome@uab.es performance of dominant plant species, reducing excessive tree or scrub encroachment, maintaining open patches within the forest, and minimizing fire hazards (Kirby et al. 1994; Vera 2001; Hulbert 2002).

The importance of Alberes cattle herds in terms of the conservation of wildlife biodiversity was emphasized by Travé (2003), but little scientific work has been undertaken regarding the composition of their diet throughout the year in semiferal grazing management, aimed at ascertaining their feeding behavior and the use of natural resources (Bartolomé et al. 2004).

The objective of this study was to determine diet selection among Alberes cattle, which have traditionally browsed in forest habitats throughout the year. The analysis focuses particularly on the spring and summer seasons, when the animals are able to choose between grassland and forest habitats, and hence express their feeding preferences. A further aim of this work was to explore the potential for brush control by this forest cow on the basis of its dietary preferences. 


\section{MATERIALS AND METHODS}

\section{Study Area}

The study area comprised the entire Baussitges estate in the Alberes Natural Park (Paratge Natural d'Interès Nacional de l'Albera, see www.gencat.cat/parcs/albera). This natural area is at the eastern end of the Pyrenees, close to the Mediterranean coast. The Alberes massif has a humid Mediterranean climate with annual average rainfall of over $1000 \mathrm{~mm}$ at the highest point (Pic Neulós, at $1256 \mathrm{~m}$ above sea level [asl]) and $700 \mathrm{~mm}$ at sea level, with most precipitation occurring in spring and autumn. The annual average temperature is approximately $15^{\circ} \mathrm{C}$. Strong winds are frequent. The soil is mainly acidic and common parent rocks are granites and slates.

The farm is 2181 ha in size, ranging from 200 to $1000 \mathrm{~m}$ asl, with 1569 ha of pasture vegetation (forest and grassland) and 612 ha of dense scrubland, which is poorly grazed.

Four hundred Alberes cattle graze on the Baussitges estate all year round and only receive supplements, such as alfalfa pellets $\left(2 \mathrm{~kg} \cdot \mathrm{head}^{-1} \cdot \mathrm{day}^{-1}\right)$, during the colder months (October to March). In spring and summer the animals graze in two habitats - the grasslands and forests in the highest parts of the mountain, whereas in the autumn and winter the animals only graze in forests on the lower slopes.

\section{Vegetation Types and Botanical Composition}

The spatial distribution of the vegetation was obtained from orthorectified aerial photographs taken in 1997 by the Cartographic Institute of Catalonia (ICC, 1998), as shown on the map in Figure 1. Four vegetation types were defined according to physiognomic and botanical attributes: 1) Mediterranean oak forests-mainly holm oak (Quercus ilex L.), but also cork oak (Quercus suber L.), and some pubescent oak (Quercus pubescens Willd.) dominate the landscape on the slopes; 2) deciduous forests of beech (Fagus sylvatica L.) and sessile oak (Quercus petraea Matt.) are only present in shady areas; 3) acidic grasslands with sheep fescue (Festuca ovina L.) and vernal sedge (Carex caryophyllea Latourr.) found at the highest altitudes; and 4) scrubland with several species of Erica and Cistus genera are in the lowland.

The distribution of the major species in the respective vegetation types was determined in the late spring (June 2003) by measuring the cover of all species along 50 transects placed in representative sites, with the use of the methodology proposed by Cummings and Smith (2000). Of these, 28 lineintercept transects of $100-\mathrm{m}$ length each were placed in the different forest habitats: 20 in Mediterranean oak forests, 2 per slope (sunny and shady) at five altitudes (300, 400, 500, 600, and $700 \mathrm{~m}$ asl), and 8 in deciduous forests, 2 per slope at 800 and $900 \mathrm{~m}$ asl. Cover of all species less than $2 \mathrm{~m}$ above ground level was obtained from the segments intercepted with the use of a $2-\mathrm{m}$ vertical stick moved over the line. The remaining 22 transects were point transects of 20-m length each, which were placed in pairs every kilometer in the grassland areas. All species encountered by a vertical needle placed every $10 \mathrm{~cm}$ along the transects were recorded.

\section{Diet Estimation}

The species composition of cattle diets was estimated by identifying epidermal fragments in the feces by microhistolog- ical analysis (Crocker 1959; Stewart 1967; García-González 1984; Bartolomé et al. 1998). This method has the advantage of providing a representative sample of the plant species ingested by animals over a number of days without interfering with animal behavior. Fresh fecal samples were collected in the field, with different fecal depositions deemed to have originated from different individuals. Field observations showed that all cows foraged in the forest in autumn and winter. In spring and summer there were two groups: One grazed in the forest and the other in the grassland, but the animals were not always the same in both groups. Each animal spent several days or even weeks in a group. The grassland group spent most of the time in this habitat, but during the hottest hours of the day cattle rested or foraged in the shade of the forest. We therefore assumed that samples from a certain habitat tended to reflect a diet that was largely selected in that habitat.

A total of 120 fecal samples were collected over a 2-yr period (2002-2004). Ten samples were collected in grasslands and 10 in forests in spring (June 2002, 2003) and summer (August 2002, 2003), and another 10 in forests in autumn (October 2002, 2003) and winter (February 2003, 2004). These samples were frozen at $-20^{\circ} \mathrm{C}$ until they were used for slide preparation. After the samples were thawed, they were water washed to remove possible adhered soil material, and then lightly ground in a mortar to separate the epidermal fragments. Ten grams from each sample were placed in test tubes with $5 \mathrm{ml}$ of $65 \%$ concentrated $\mathrm{HNO}_{3}$. The test tubes were then boiled in a water bath for $1 \mathrm{~min}$. After digestion in $\mathrm{HNO}_{3}$, the samples were diluted with $200 \mathrm{ml}$ of water. This suspension was then passed through 1.00 - and $0.25-\mathrm{mm}$ filters. The $0.25-1.00-\mathrm{mm}$ fraction was spread on glass microscope slides in a $50 \%$ aqueous glycerine solution. Two slides were prepared from each sample. The slides were examined under a microscope at $\times 100-\times 400$ magnifications by viewing 2-mm-wide and 60 mm-long traverses, with $3 \mathrm{~mm}$ between traverses. Plant fragments in each traverse were recorded and counted until 200 fragments of leaf epidermis were identified from each sample. An epidermis collection of plant species of the area was used to identify epidermal fragments. Fragments from alfalfa pellets were not detected in fecal samples.

\section{Preference Index}

Preference or rejection of the main vegetation species was calculated as a function of its occurrence in the diet and its availability to the herbivore (Westoby 1978; Belovsky 1981; Crawley 1983). Availability was estimated as the vegetation composition accessible to the grazing animal. The overall availability of species $i$ for the whole study area, $V_{i}$, was calculated by weighting the cover of the species in each vegetation type by the proportion of the study area occupied by the vegetation type. Preference or aversion in spring (employing the 10 grassland samples and the 10 forest samples collected in June 2003) for each species was then estimated using the Ivlev electivity index, $S_{i}$ (Ivlev 1961):

$$
S_{i}=\left(D_{i}-V_{i}\right) /\left(D_{i}+V_{i}\right),
$$

where $D_{i}$ is the proportion of species $i$ in the diet number of epidermal fragments of species $i$ divided by the total number of 


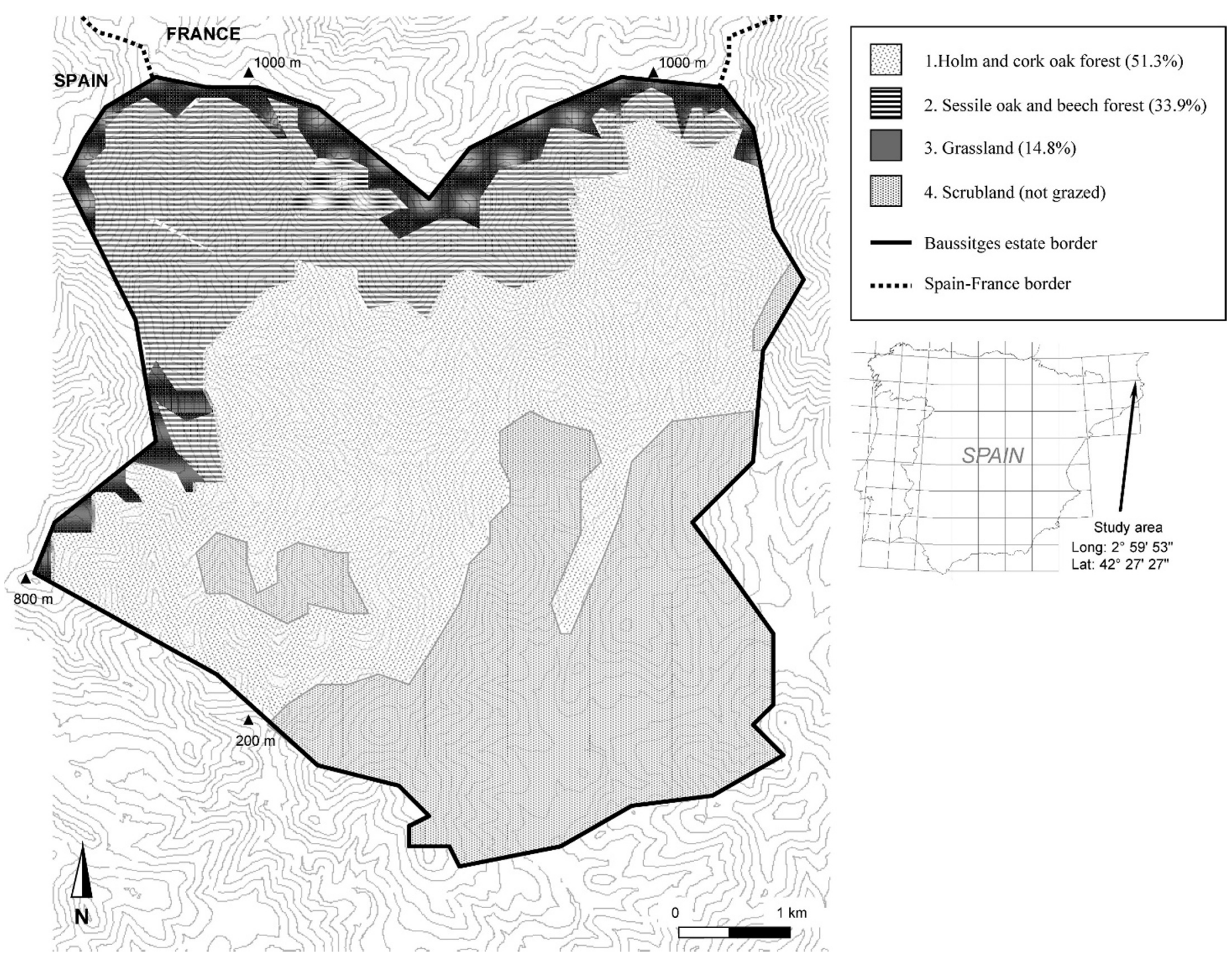

Figure 1. Topographic map of the study area (Baussitges estate), showing the vegetation types and area covered, expressed as percentage (in brackets) of total area grazed by cattle (which excludes scrubland).

epidermal fragments in the feces sample), and $V_{i}$ is the overall availability of species $i$ defined above. A positive index close to +1 indicates preference, a negative index close to -1 indicates avoidance, and values close to zero indicate indifference.

\section{Statistical Analysis}

Descriptive statistics were calculated for the entire diet data set, grouped into the following components: Erica spp., Quercus spp., other woody species, forbs, and graminoids. Means, standard errors, and standard deviations were computed for the quantitative variables and frequencies were obtained for qualitative variables.

In order to normalize the data, percentages of epidermal fragments of each component were arcsin (angular) transformed (Sokal and Rohlf 1969) before statistical analysis. The sampling strategy was not balanced, because animals only grazed both habitats (grassland and forest) in spring and summer, and they grazed exclusively in forest habitats in autumn and winter. Three factors that could influence the diet composition in the spring and summer period were tested by a factorial ANOVA (SAS Institute, Inc.): year (1 and 2), season (spring and summer), and the habitat in which the feces sample was collected (grassland and forest). Only two factors were considered for the forest habitat data over the whole year: year (1 and 2) and season (spring, summer, autumn, and winter). Significant differences were determined by Fisher's Protected LSD (Fisher 1949).

\section{RESULTS}

Forest occupied $85 \%$ of the estate area grazed by cattle, and grassland, exclusively located at the top of the mountains, covered the rest (Fig. 1). Mediterranean forest was the largest component, occupying more than $50 \%$ of the area (Fig. 1). The absolute cover of the vegetation below $2 \mathrm{~m}$ above ground level (available for cattle) was close to $50 \%$ in both Mediterranean and deciduous forest areas and $100 \%$ in the grassland area (Table 1), and this was dominated by bushes of Erica genus in the Mediterranean forest area (Table 1). 
Table 1. Total vegetation cover (\%) in the three main vegetation types of the Baussitges estate in the Alberes Natural Area of National Interest, and its breakdown according to species grouping.

\begin{tabular}{lccc}
\hline & \multicolumn{3}{c}{ Vegetation type } \\
\cline { 2 - 4 } & $\begin{array}{c}\text { 1. Holm and } \\
\text { cork 0ak forest }\end{array}$ & $\begin{array}{c}\text { 2. Sessile oak and } \\
\text { beech forest }\end{array}$ & 3. Grassland \\
\hline Total vegetation cover $^{1}$ & 47.7 & 48.7 & 100 \\
Erica spp. $^{2}$ & 54.7 & 9.5 & 0 \\
Quercus spp. $^{3}$ & 17.8 & 8.1 & 0 \\
Other woody plants & 15.6 & 23.7 & 0 \\
Forbs $_{\text {Graminoids }}$ & 3.9 & 32.8 & 43.1 \\
\hline
\end{tabular}

${ }^{1}$ Plant cover less than $2 \mathrm{~m}$ above ground level (available for cattle).

${ }^{2}$ Includes Erica arborea and Erica scoparia.

${ }^{3}$ Includes Quercus ilex, Quercus suber, Quercus pubescens, and Quercus petraea.

For fecal samples collected in forest habitat in all seasons of the year, differences in diet composition due to Season and the interaction between Season and Year were significant for all diet components $(P<0.01)$. Erica spp. reached maximum values in winter and the minimum in spring, whereas Quercus spp. attained maximum and minimum values in autumn and summer, respectively (Table 2). Graminoids peaked in spring, and forbs and other woody species were more prominent in summer. These three components dropped to lower levels in winter. The factor Year was only significant for graminoids $(P<0.01)$, for which the number of epidermal fragments in the second year fell by $37 \%$. The interaction between Year and Season was due to the fact that the main woody components, Quercus spp. and Erica spp., attained the highest values in the autumn and winter of the second year (65\% and $43 \%$, respectively), when the herbaceous components, graminoids and forbs, fell to their minimum values ( $5 \%$ and $0.3 \%$, respectively).

In the June-September period, when samples were provided from two different habitats (forest and grassland), Season (spring or summer) and Habitat were significant for most of the components (Table 3). A relatively high proportion of fecal epidermal fragments was obtained in spring for Quercus spp. and graminoids, and in summer for the other components (Fig. 2). Habitat was a relevant factor in these data, indicating that differences in diet composition were related to habitat preferences: Woody components dominated in forest samples, and herbaceous components in grassland samples. The year only affected Erica spp., which fell from 19\% in 2002 to 14\% in 2003. Forbs were the component most affected by the interaction of the three factors, and were more prominent in 2003 (11\% of the diet), but not in the spring in forest habitat.
Table 2. Prevalence (\%) of the main species groupings in the diet of Alberes cattle as determined from fecal samples collected in the forest habitat, according to season of sampling. ${ }^{1}$

\begin{tabular}{lrrrr}
\hline & Spring & Summer & Autumn & Winter \\
\hline Erica spp. & $14.5 \mathrm{c}$ & $26.9 \mathrm{~b}$ & $23.1 \mathrm{~b}$ & $39.4 \mathrm{a}$ \\
Quercus spp. & $41.6 \mathrm{~b}$ & $23.9 \mathrm{c}$ & $53.4 \mathrm{a}$ & $40.5 \mathrm{~b}$ \\
Other woody plants & $5.9 \mathrm{~b}$ & $16.1 \mathrm{a}$ & $4.6 \mathrm{~b}$ & $8.8 \mathrm{~b}$ \\
Forbs & $7.3 \mathrm{a}$ & $9.9 \mathrm{a}$ & $3.2 \mathrm{~b}$ & $0.9 \mathrm{~b}$ \\
Graminoids & $27.0 \mathrm{a}$ & $11.5 \mathrm{~b}$ & $10.6 \mathrm{~b}$ & $8.4 \mathrm{~b}$
\end{tabular}

${ }^{1}$ Different letters in the same row indicate significant differences.

The Ivlev electivity index in spring showed a preference for Quercus spp. $\left(S_{i}=0.44\right)$, a moderate preference for graminoids $\left(S_{i}=0.16\right)$, and a moderate aversion to Erica spp. $\left(S_{i}=-0.26\right)$, other woody species $\left(S_{i}=-0.20\right)$, and forbs $\left(S_{i}=-0.14\right)$.

\section{DISCUSSION}

The bulk of the diet of the Alberes cattle population was made up of woody species, mainly from the Quercus genus, which turned out to be the most preferred component of the diet. The Quercus and Erica genera and the other woody forest species accounted for $62 \%$ to $89 \%$ of fecal epidermal fragments in forest samples, reflecting the fact that the animals grazed intensively in Mediterranean forest. The maximum values for both genera, Quercus in autumn and Erica in winter, must be related to the shortage of herbaceous components during these periods and the phenology of both species. Quercus produces acorns in the autumn, and even though these fruits are not detected in fecal analysis, they could act as attractants for livestock. The period of Erica flowering begins in late winter, and the presence of flowers is probably also an attractant for livestock. The woody components were also important in samples collected in grassland, where they accounted for more than one-third of the fragments. Forbs made up the smallest fraction of diets, probably because of their more fragile epidermal components, which may create bias in their estimation (Holechek et al. 1982; Bartolomé et al. 1995). The interaction of the three factors studied with regard to this component was probably due to the well-known annual variability of herbaceous production in Mediterranean pastures, where various environmental factors such as precipitation, temperature, and availability of nutrients are involved (Gutman et al. 1990).

In spring and summer, feces collected in different habitats differed in the diet composition that they reflected, even though

Table 3. Statistical significance of Season (spring, summer), Year (1, 2), and Habitat (grassland, forest) effects on the main diet components of Alberes cattle in the June-September period. ${ }^{1}$

\begin{tabular}{|c|c|c|c|c|c|c|c|}
\hline & Season (S) & $\operatorname{Year}(\mathrm{Y})$ & Habitat $(\mathrm{H})$ & $S \times Y$ & $\mathrm{~S} \times \mathrm{H}$ & $\mathrm{Y} \times \mathrm{H}$ & $\mathrm{S} \times \mathrm{H} \times \mathrm{Y}$ \\
\hline Erica spp. & $* * *$ & ** & $\star * *$ & ns & * & * & ns \\
\hline Quercus spp. & $* * *$ & ns & $\star \star \star$ & ns & ns & ns & ns \\
\hline Other woody plants & $* * *$ & ns & ns & $\mathrm{ns}$ & ns & ** & ns \\
\hline Forbs & $\star \star$ & ns & $\star \star$ & ns & ns & $\mathrm{ns}$ & $\star \star *$ \\
\hline Graminoids & $\star \star *$ & ns & $\star \star \star$ & ns & * & ns & * \\
\hline
\end{tabular}

${ }^{1 *}$ indicates $P<0.05 ;{ }^{* *}, P<0.01 ;{ }^{* * *}, P<0.001$; ns, not significant. 

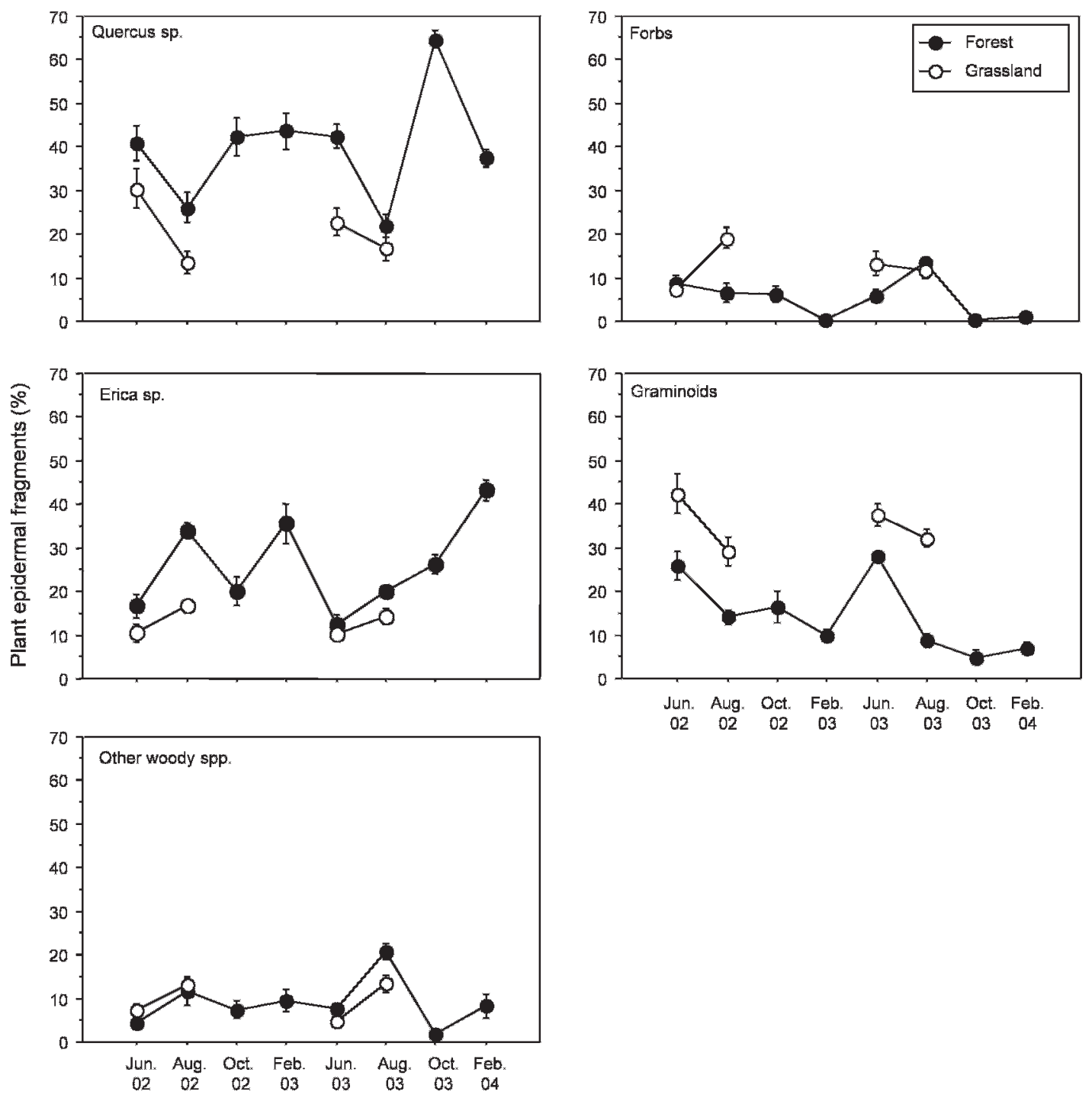

Figure 2. Mean percentage of main diet components of Alberes cattle during a 2-yr study period (June 2002 to February 2004), as estimated by microhistological analysis of feces.

animals had free access to all habitats. Given that domestic bovines have been considered preferential grazers and are not known to be browsers (Putman et al. 1987; Hofmann 1989), and that the animals could choose between the two habitats in these two seasons, a preference for grassland habitat and a diet clearly dominated by herbaceous components would be expected. However, field observations and results showed that the Alberes cattle also grazed actively in the forests, and that even the feces collected from grassland contained one-third of woody species. This is probably the result of time spent in resting places in the forest during the hottest hours. These amounts are similar to those observed among selective browsers (Jackson 1980; Heroldová 1996; Bartolomé et al. 2002), and are very high for a bovine population.

The low values for preference for graminoids and aversion to forbs suggested that the herbaceous fraction could be in the indifference range of the Alberes cattle diet selection in spring. The abundance of these components in the diet should therefore only be dependent on their availability in the vegetation. In addition, the moderate aversion to Erica sp. and other woody species indicated that the feeding behavior of this population is quite different from that of a selective browser. These results are consistent with those of other authors (Nygren and Hofmann 1990; Clauss and Lechner-Doll 2001), who reported differences in the typology of fecal particles between browser species and cattle.

Alberes cows cannot be considered browser animals because the moderate values of the Ivlev electivity index, $S_{i}$, ranging from -0.26 to 0.44 , suggest that their diet selection is more closely related to the availability of each plant component in the vegetation than to animal preferences. Nevertheless, they can live in a forestry habitat all year round with little forage supplementation. The obvious rusticity and adaptability of the Alberes cattle to forest resources are reflected in their diet, in which the dominant woody species predominate. Some of them are highly flammable throughout the year, such as the Erica genus (Moreno and Cruz 2000). This aspect is currently of particular interest, mainly in protected areas, and this breed could play a potential role in prescribed browsing for controlling forest encroachment and reducing fire hazards. Other domestic species have been used for this purpose, such as goats or sheep (Etienne et al. 1996; Valderrábano and Torrano 
2000), but the body size of cattle implies greater impacts on the plant structure due to trampling and browsing.

\section{MANAGEMENT IMPLICATIONS}

The special attributes of Alberes cattle-a hardy animal with a predominance of forest feeding-suggest that other options are possible when the management of natural resources and landscapes are associated with free-ranging grazing animals. Most woods have been grazed by some large herbivores and the ecosystem has been sustainable over time. Cattle can substitute wild herbivores when they have disappeared. In the Alberes Natural Park, cattle grazing is a traditional use of woodlands that has persisted, and foraging activity probably affects the performance of some dominant plant species, such Erica or Quercus. In that regard, this type of animal could be an effective tool for reducing fuel biomass in Mediterranean forests and could also help identify appropriate management regimes for woodlands that recognize the role of livestock and the conservation benefits that they confer.

\section{ACKNOWLEDGMENTS}

The collaboration of A. Carola, owner of the animals, and Rosa Cordoner is greatly appreciated. Valuable comments by M. Josep Broncano are gratefully acknowledged.

\section{REFERENCES}

Bartolomé, J., J. Franch, M. Gutman, and N. G. Seligman. 1995. Physical factors that influence fecal analysis estimates of herbivore diets. Journal of Range Management 48:267-270.

Bartolomé, J., J. Franch, J. Plaixats, J, and N. G. Seligman. 1998. Diet selection by sheep and goats on Mediterranean heath-woodland. Journal of Range Management 51:383-391.

Bartolomé, J., J. Piedrafita, and J. Plaixats. 2004. Preliminary results on diet composition by the Alberes semi-feral cattle breed. Advances in Geoecology 3:203-208.

Bartolomé, J., C. Rosell, and E. Bassols. 2002. Diet composition of roe deer (Capreolus capreolus) in the natural park of the Garrotxa Volcanic Zone (Catalonia, Spain). Pirineos 157:57-63.

Belovsky, G. E. 1981. Food plants selection by a generalist herbivore, the moose. Ecology 62:1020-1030.

Budó, J. 2000. Un cop d'ull a L'Albera. La Jonquera, Spain: Ed. L’Esquerda de la Bastida.

Casellas, J., N. Jiménez, M. Fina, J. Tarrés, A. Sánchez, and J. Piedrafita. 2004. Genetic diversity measures of the bovine Alberes breed using microsatellites: Variability among herds and types of coat colour. Journal of Animal Breeding and Genetics 121:101-110.

Clauss, M., and M. LeChner-Doll. 2001. Differences in selective reticulo-ruminal particle retention as a key factor in ruminant diversification. Oecologia 129:321-327.

Crawley, M. J. 1983. Herbivory: The dynamics of animal-plant interactions. Studies in ecology. Volume 10. Oxford, United Kingdom: Blackwell Scientific.

Crocker, B. H. 1959. A method of estimating the botanical composition of the diet of sheep. New Zealand Journal of Agriculture Research 2:72-85.

Cummings, J., AND D. Smith. 2000. The line-intercept method: A tool for introductory plant ecology laboratories. In: S. J. Karcher [ED.]. Tested studies for laboratory teaching. Volume 22. Proceedings of the 22nd Workshop/Conference of the Association for Biology Laboratory Education (ABLE); 6-10 June 2000; Clemson, SC, USA. $489 \mathrm{p}$.

Etienne, M., M. Derzko, and E. Rigolot. 1996. Browse impact in silvopastoral systems participating in fire prevention in the French Mediterranean region. In: M. Etienne [ED.]. Versailles, France: Western European Silvopastoral Systems. INRA. p. 93-102.

Fina, M., J. Casellas, J. Tarres, J. Bartolomé, J. Plaixats, X. Such, N. Jiménez, A. Sánchez, and J. Piedrafita. 2008. Characterisation and conservation programme of the Alberes cattle breed in Catalonia (Spain). FAO. Animal Genetic Resources Information 43:1-14.

Fisher, R. A. . The design of experiments. Edinburg, United Kingdom: Oliver \& Boyd.

García-Gonzálezz, R. 1984. L'emploi des epidermes végétaux dans la détermination du régime alimentaire de l'Isard dans les Pyrénées occidentales. Écologie des milieux montagnards et de haute altitude. Documents d'Ėcologie Pyrénéenne III-IV:307-313.

Gutman, M., N. G. Seligman, and I. Noy-Meir. 1990. Herbage production of Mediterranean grassland under seasonal and yearlong grazing systems. Journal of Range Management 43(1):64-68.

Heroldová, M. 1996. Dietary overlap of three ungulate species in the Palava biosphere reserve. Forest Ecology and Management 88:139-142.

Hofmann, R. R. 1989. Evolutionary step of ecophysiological adaptation and diversification of ruminants: a comparative view of their digestive system. Oecologia 78:443-457.

Holecheck, J. L., M. Vavra, and R. D. Pieper. 1982. Botanical composition determination of range herbivore diets. A review. Journal of Range Management 35:309-315

HULBERT, I. A. R. 2002. Livestock grazing of woodlands-impact and management options. Scottish Forestry 56:5-16.

Institut Cartográfic de Catalunya (ICC). 1998. Ortofotomapa de Catalunya, 1:25.000. Generalitat de Catalunya. Departament de Política Territorial i Obres Públiques.

IVLEV, V. S. 1961. Experimental ecology of the feeding fishes. New Haven, CT: Yale University Press.

JaCkSON, J. 1980. The annual diet of the Roe deer (Capreolus capreolus) in the New Forest, Hampshire, as determined by rumen content analysis. Journal of Zoology 192:71-83.

KirBy, K. J., F. J. G. Mitchell, and A. J. Hester. 1994. A role for large herbivores (deer and domestic stock) in nature conservation management in British semi-natural woods. Arboricultural Journal 18:381-399.

Mascort MarianI, L. 1957. La raza vacuna de las Alberes. Archivos de Zootecnia 6:107-150.

Moreno, J. M., and A. Cruz. 2000. La respuesta de las plantas al fuego. In: R. Velez (COORD.). La defensa contra incendios forestales. Fundamentos y experiencias. Madrid, Spain: McGraw Hill. p. 413-436.

Nygren, K., and R. R. Hofmann. 1990. Seasonal variation of food particle size in moose. Alces 26:44-50.

Putman, R. J., R. M. Pratt, J. R. Ekins, and P. J. Edwards. 1987. Food and feeding behaviour of cattle and ponies in the New Forest, Hampshire. Journal of Applied Ecology 24(2):369-380.

Sokal, R. R., and F. J. Rohlf. 1969. Biometry. San Francisco, CA: W.H. Freeman.

Stewart, D. R. M. 1967. Analysis of plant epidermis in faeces, a technique for studying the food preferences of grazing herbivores. Journal of Applied Ecology 4:83-111.

TrAVÉ, J. 2003. Dead wood and saproxylic complex in the Massane forest. Role in the conservation of invertebrates. In: People trust for endangered species. Proceedings of the Second Pan-European Conference on Saproxilic Beetles; Gland, Switzerland. p. 1-4.

Valderrábano, J., and L. Torrano. 2000. The potential for using goats to control Genista scorpius shrubs in European black pine stands. Forest Ecology and Management 126(3):377-383.

Vera, F. W. M. 2001. Grazing ecology and forest history. CABI Publishing, Oxford. Westoby, M. 1978. What are the biological bases of varied diets? American Naturalist 112:627-631. 